\title{
PERAN PENYIDIK DALAM PENERAPAN DIVERSI TERHADAP PERKARA TINDAK PIDANA ANAKDI WILAYAH KABUPATEN POHUWATO (STUDI KASUS DI POLRES POHUWATO)
}

\author{
OLEH : \\ MUHAMMAD RIZAL LAMPATTA \\ EMAIL : rlampatta@gmail.com \\ DOSEN FAKULTAS HUKUM \\ UNIVERSITAS ICHSAN GORONTALO
}

\begin{abstract}
The perpetrator of the criminal act of the child cannot be equated with criminal adults. Therefore, it needs more attention in the case of children. However, the child is the successor Nations that should be developed physically and mentally. The purpose of this research is to analyze the role of the Ombudsman in the performance of Marisa Polres versioned as well as analyze constraints are faced by Investigators in implementation Marisa Polres versioned. This type of research is research used empirical research focus i.e. normative on secondary data sources (research libraries). This research uses the main data source, i.e. secondary data, backed up with primary data sources. Secondary data is used that is derived from legislation such as the ACT on criminal justice system of the child, the child protection ACT, Act No. 8 Of 1981 Year Book of the Police Act, Police ACT and some of the literature-literature as well as the results of his research, and books related to the role of the Ombudsman in conducting versioned on criminal act committed by the child. Research results show that Marisa Polres in performing the investigation is a criminal act committed by the child by women and children protection Unit (UPPA). Starting from the stage of investigation, arrest, detention up at the stage of investigation conducted in accordance with the mandate of the ACT on the criminal justice system. Investigators in conducting versioned, get consideration from BAPAS. In addition, the investigators also act/mediator to conduct deliberations involving the child and the parent/guardian, the victim and the parent/guardian, supervisor of community, social professional worker based on approach restorative. Obstacles faced by Investigators in the conduct of Marisa Polres diversion that is not yet the existence of BAPAS in counties Marisa so complicate investigators to coordinate in terms of asking for consideration in doing versioned. In addition the party victims sometimes do not want to make peace so that the attempted diversion by Investigators was not achieved.
\end{abstract}

Key Words: Diversion, Crime, Police 


\section{A. PENDAHULUAN}

Kejahatan adalah suatu perilaku yang menyimpang tanpa memandang jenis kelamin maupun usia bagi para pelakunya, baik laki-laki atau perempuan, baik tua atau maupun muda. Suatu permasalahan yang cukup sulit dalam hal membicarakan materi kejahatan ini ,karena seperti yang telah kita ketahui bahwa manusia dengan segala keadaannya masih mempunyai kecenderungan untuk melakukan kejahatan apapun latar belakangnya.

Salah satu hukum tertulis, misalnya hukum pidana menyebutkan bahwa seseorang yang melakukan tindak pidana baik kejahatan maupun pelanggaran akan dikenakan sanksi, sesuai dengan apa yang diatur dalam Buku kedua dan Buku ketiga Kitab Undang-Undang Hukum Pidana.

Dasar dari pada adanya tindak pidana menurut ahli hukum, adalah :

"azas legalitas, yaitu azas yang menentukan bahwa tidak ada perbuatan yang dilarang dan diancam dengan pidana jika tidak ditentukan terlebih dahulu dalam perundangundangan. Biasanya azas legalitas tersebut mengandung tiga pengertian, yaitu :

1) Tidak ada perbuatan yang dilarang dan diancam dengan pidana kalau hal ini terlebih dahulu belum dinyatakan dalam suatu aturan undangundang.

2) Untuk menentukan adanya perbuatan pidana tidak boleh digunakan analogi.

3) Aturan-aturan hukum pidana tidak berlaku surut" . (Roeslan Saleh,1983. 40)

Dari pengertian diatas dapat kita ketahui, bahwa untuk setiap perbuatan ada yang mengaturnya secara tegas. Dan akan dikenakan sanksi apabila dalam perbuatan tersebut terdapat suatu kesalahan. Dimana menurut Kitab Undang-undang Hukum Pidana, suatu bentuk kesalahan adalah perbuatan tersebut harus dilakukan dengan unsur kesengajaan atau kelalaian, dan disamping itu orang tersebut harus mampu mempertanggung jawabkan perbuatannya.

Menurut pasal 44 ayat 1 KUHP, maka :

"Barang siapa mengerjakan sesuatu perbuatan, yang tidak dapat dipertanggung jawabkan kepadanya karena kurang sempurna akalnya atau karena sakit berubah 'akal tidak boleh dihukum". 
Dalam hal ini seseorang yang melakukan tindak pidana, selalu dihubungkan dengan mampu atau tidaknya mempertanggung jawabkan perbuatannya dan disamping itu melenyapkan pertanggungan jawab anak dibawah umur, sebab dalam hal tindak pidana yang dilakukan oleh anak dibawah umur, maka berdasarkan pasal 45 KUHP hakim dapat menentukan untuk tidak menghukum. karena tidak mampu mempertanggung jawabkan perbuatannya dengan menyerahkan kepada orang tuanya, atau menyerahkan kepada pemerintah untuk dididik tanpa dijatuhi hukuman.

Akan tetapi pasal ini dinyatakan sudah tidak berlaku lagi dengan dikeluarkannya peraturan yang khusus yaitu Undang - undang Nomor 3 Tahun 1997 tentang pengadilan anak, dengan maksud melindungi dan mengayomi anak yang berhadapan dengan hukum melalui pembinaan untuk menjadi manusia yang mandiri, bertanggung jawab, dan berguna bagi diri sendiri, keluarga, masyarakat, bangsa dan Negara. Namun seiring berjalannya waktu, Undang-Undang tersebut tidak lagi relevan dengan keadaan yang terjadi di masa sekarang maka diperbarui dan munculah Undang-undang Nomor 11 Tahun 2012 tentang Sistem Peradilan Pidana Anak.

Menurut Undang-Undang 11 Tahun 2012 tentang Sistem Peradilan Pidana Anak, yang dimaksud dengan anak yang berhadapan dengan hukum dibagi menjadi 3 (tiga) golongan yaitu anak yang berkonflik dengan hukum ; anak yang menjadi korban tindak pidana ; dan anak yang menjadi saksi tindak pidana (Angger Sigit Pramukti \& Fuadi Primaharsya,2015:17). Bagi pelaku tindak pidana anak tidak dapat disamakan dengan pidana orang dewasa. Maka dari itu dibutuhkan perhatian lebih dalam kasus anak.Bagaimanapun juga anak merupakan penerus bangsa yang harus dikembangkan secara fisik maupun mental. Sistem Peradilan Pidana di dalam UndangUndang No 11 Tahun 2012 terdapat konsep keadilan restoratif dan diversi yang dapat memberikan sanksi terhadap pelaku pidana anak dengan tetap memperhatikan hak anak.

Dalam pendekatan keadilan restoratif dan diversi, digunakan sebagai bentuk pembinaan yang positif terhadap pelaku pidana anak dimana melibatkan antara pihak korban dan pihak pelaku. Selain itu, diperlukan juga peran pihak yang berwenang dalam melaksanakan pendekatan tersebut. Pada pendekatan ini lebih mengutamakan kepentingan anak sebagai pelaku dalam perbaikan masa depan dan diri anak. Proses 
diversi merupakan pengalihan perkara Anak dari proses peradilan pidana ke proses diluar peradilan pidana yang dilaksanakan selama tahap penyelesaian perkara anak dari penyidikan, penuntutan, dan pemeriksaan di pengadilan negeri.

Tujuan dari diversi adalah untuk mendapatkan cara menangani pelanggaran hukum di luar pengadilan atau sistem peradilan yang formal. Ada kesamaan antara tujuan diskresi dan diversi. Pelaksanaan diversi dilatarbelakangi keinginan menghindari efek negatif terhadap jiwa dan perkembangan anak oleh keterlibatannya dengan sistem peradilan pidana. Pelaksanaan diversi oleh aparat penegak hukum didasari oleh kewenangan aparat penegak hukum yang disebut discretion atau diskresi". (Marlina, 2010:1)

Berdasarkan latar belakang yang telah penulis kemukakan sebelumnya maka pokok permasalahan yang akan penulis bahas dalam penelitian ini adalah Bagaimanakah Peran Penyidik Polres Pohuwato dalam pelaksanaan diversi dan Kendala - kendala apakah yang dihadapi oleh Penyidik Polres Pohuwato dalam pelaksaan diversi.

\section{B. METODE PENELITIAN}

Berdasarkan permasalahan pokok yang dikemukakan di atas, maka dalam skripsi ini penulis menggunakan tipe penelitian normatif empiris yaitu memusatkan penelitian pada sumber-sumber data sekunder (penelitian kepustakaan). Selain itu untuk mendukung data sekunder, juga dilakukan tipe penelitian yuridis empiris yaitu melakukan penelitian dengan cara mengumpulkan data primer yang didapat dari wawancara dari beberapa narasumber terkait yang berhubungan dengan pokok masalah yang dibahas.

Penelitian ini menggunakan sumber data utama yaitu data sekunder, yang didukung dengan sumber data primer. Data sekunder yang digunakan yaitu berasal dari peraturan perundang-undangan seperti UU tentang Sistem Peradilan Pidana Anak, UU Perlindungan Anak, UU No. 8 Tahun 1981 Tentang Kitab Undang-Undang Kepolisian, UU Kepolisian dan beberapa literatur - literature serta hasil-hasil penelitian, dan bukubuku yang berkaitan dengan peran penyidik dalam melakukan diversi pada tindak pidana yang dilakukan oleh anak. 
Data Primer yang digunakan adalah wawancara dengan narasumber yakni Aparat Kepolisian dalam hal ini Penyidik pada Unit Perlindungan Perempuan dan Anak Polres Pohuwato yang menangani penyidikan pada tindak pidana anak.

\section{HASIL PENELITIAN DAN PEMBAHASAN}

\section{Upaya Penyidik Polres Pohuwato dalam Pelaksanaan Diversi}

Pelaksanaan diversi dan restorative justice pada anak yang berhadapan dengan hukum telah diatur dengan sedemikian rupa pada Undang-Undang no. 11 tahun 2012 tentang Sistem Peradilan Pidana Anak yang bertujuan khusus untuk mencegah jangan sampai anak mengalami pelabelan sebagai penjahat.

Menurut Marlina (2010:97-97) Beberapa kriteria tindak pidana yang melibatkan anak sebagai pelaku, yang harus diupayakan penyelesaiannya dengan pendekatan prinsip diversi adalah:

1. Kategori tindak pidana yang diancam dengan sanksi pidana sampai dengan 1 (satu) tahun harus diprioritaskan untuk diterapkan diversi, tindak pidana yang diancam dengan sanksi pidana di atas 1 (satu)

2. tahun sampai dengan 5 tahun dapat dipertimbangkan untuk melakukan diversi, semua kasus pencurian harus diupayakan penerapan diversi kecuali menyebabkan atau menimbulkan kerugian yang terkait dengan tubuh dan jiwa;

3. Memperhatikan usia pelaku, semakin muda usia pelaku, maka urgensi penerapan prinsip diversi semakin diperlukan;

4. Hasil penelitian dari BAPAS, bila ditemukan faktor pendorong anak terlibat dalam kasus pidana adalah faktor yang ada di luar kendali anak maka urgenitas penerapan prinsip diversi semakin diperlukan;

5. Kerugian yang ditimbulkan oleh tindak pidana anak, bila akibat yang ditimbulkan bersifat kebendaan dan tidak terkait dengan tubuh dan nyawa seseorang maka urgenisitas penerapan diversi semakin diperlukan;

6. Tingkat keresahan masyarakat yang diakibatkan oleh perbuatan anak;

7. Persetujuan korban/keluarga.;

8. Kesediaan pelaku dan keluarganya; 
9. Dalam hal anak melakukan tindak pidana bersama-sama orang dewasa maka orang dewasa harus diproses hukum sesuai dengan prosedur biasa.

Konsep diversi sebagai suatu perwujudan dari tindakan diskresi sebenarnya telah diberikan kepada penyidik jauh sejak UU tentang Sistem Peradilan Anak dibuat yakni terdapat di dalam Undang - Undang No. 8 Tahun 1981 Tentang Hukum Acara Pidana (KUHAP) di dalam Pasal 7 ayat (1) huruf J :Penyidik sebagaimana dimaksud dalam pasal 6 ayat (1) huruf a karena kewajibanya mempunyai kewenangan :

j. Mengadakan tindakan lain menurut hukum yang bertanggung jawab

Yang dimaksud dengan penyidik adalah pejabat polisi ataupun pejabat pegawai negri sipil tertentu yang diberi wewenang khusus oleh undang-undang. Pada pasal ini polisi maupun pegawai negri sipil diberikan peluang untuk melakukan penyidikan dengan menggunakan cara selain oleh apa yang telah diatur sebelumnya. Masih pada undang-undang yang sama, pada pasal 137 dan 139 KUHAP dinyatakan, penuntut umum berwenang melakukan penuntutan pada siapa pun dan berhak menentukan apakah berkas penyidikan dapat dilimpahkan ke pengadilan atau tidak. Pasal 7 ayat (1) huruf J, pasal 137 dan pasal 139 KUHAP merupakan beberapa pasal yang telah memberikan peluang pada pihak berwajib terkait untuk melakukan tindakan lain diluar oleh apa yang diatur. Dalam hal ini walaupun mengenai diversi tidak diatur secara tegas dalam KUHAP namun telah terlihat adanya peluang untuk melakukan diversi.

Selain itu pada pasal 18 ayat (1) dan (2)UndangUndang no. 2 tahun 2002 tentang Kepolisian mengenai menjalankan tugas dan wewenang dengan penilaian sendiri dan pada pasal 16 ayat (1) huruf L dan pasal 16 ayat (2) yaitu :

(1) Dalam rangka menyelenggarakan tugas sebagaimana dimaksud dalam pasal 13 dan pasal 14 di bidang proses pidana, Kepolisian Negara Republik Indonesia berwenang untuk :

l. Mengadakan tindakan lain menurut hukum yang bertanggung jawab.

(2) Tindakan lain sebagaimana dimaksud dalam ayat (1) huruf 1 adalah tindakan penyelidikan dan penyidikan yang dilaksanakan jika memenuhi syarat sebagai berikut :

a. tidak bertentangan dengan suatu aturan hukum 
b. selaras dengan kewajiban hukum yang mengharuskan tindakan tersebut dilakukan

c. harus patut, masuk akal, dan termasuk dalam lingkungan jabatannya

d. pertimbangan yang layak berdasarkan keadaan yang memaksa

e. menghormati hak asasi manusia

Sistem peradilan anak wajib mengutamakan pendekatan keadilan restorative pada tingkat penyidikan dan penuntutan, pada tahap persidangan dan pada saat pembinaan, pembimbingan, pengawasan dan/atau pendampingan selama proses pelaksanaan pidana atau tindakan dan setelah menjalani pidana atau tindakan (Pasal 5 UU SPPA). Selanjutnya mengenai penerapan diversi terhadap anak yang berhadapan dengan hukum dilakukan pada tiga tingkatan yakni pada tingkat penyidikan, penuntutan dan pemeriksaan di pengadilan sesuai dengan amanat UU Sistem Peradilan Anak yakni dalam Pasal 7 UU SPPA:

(1) Pada tingkat penyidikan, penuntutan, dan pemeriksaan perkara Anak di pengadilan negeri wajib diupayakan Diversi.

(2) Diversi sebagaimana dimaksud pada ayat (1) dilaksanakan dalam hal tindak pidana yang dilakukan:

a. diancam dengan pidana penjara di bawah 7 (tujuh) tahun; dan

b. bukan merupakan pengulangan tindak pidana

Berdasarkan pasal tersebut suatu kasus tindak pidana anak yang melakukan tindak pidana diatas 7 tahun dan pengulangan tindak pidana tidak di upayakan diversi. Keputusan mengenai apakah suatu kasus anak akan diselesaikan dengan langsung menggunakan diversi atau tidak diberikan kepada penyidik yang terlebih dahulu bekerja sama dan menerima pendapat dari pembimbing kemasyarakatan dan juga pekerja sosial professional.

\section{Kendala Yang Dihadapi Oleh Polres Pohuwato Dalam Pelaksanaan Diversi.}

Diversi dimaksudkan untuk menghindari dan menjauhkan anak dari proses peradilan sehingga dapat menghindari stigmatisasi terhadap anak yang berhadapan dengan hukum dan diharapkan anak dapat kembali ke dalam lingkungan sosial secara wajar. Oleh karena itu, sangat diperlukan peran serta semua pihak dalam rangka 
mewujudkan hal tersebut. Proses itu harus bertujuan pada terciptanya keadilan restoratif, baik bagi anak maupun bagi korban. Keadilan restoratif merupakan suatu proses diversi yaitu dimana semua pihak yang terlibat dalam suatu tindak pidana tertentu bersama-sama mengatasi masalah serta menciptakan suatu kewajiban untuk membuat segala sesuatunya menjadi lebih baik dengan melibatkan korban, anak, dan masyarakat dalam mencari solusi untuk memperbaiki, rekonsiliasi, dan menenteramkan hati yang tidak berdasarkan pembalasan. (Apshari Pinatih dan Rai Setiabudi, http://ojs.unud.ac.id/index.php/kerthawicara/article/viewFile/8316/6199)

Penerapan ketentuan diversi merupakan hal yang penting, karena dengan diversi hak-hak asasi anak dapat lebih terjamin, dan menghindarkan anak yang berhadapan dengan hukum dari stigma sebagai anak nakal, karena tindak pidana yang diduga melibatkan seorang anak sebagai pelaku dapat ditangani tanpa perlu melalui proses hukum. (Lushiana Primasari, http://lushiana.staff.uns.ac.id/pdf)

Pelaksanaan diversi sebagai suatu tindakan menuju suatu keadilan yang restorative selalu diupayakan oleh Penyidik Polres Pohuwato dalam melakukan penyidikan tindak pidana yang dilakukan oleh anak. Tindak pidana yang dilakukan oleh anak di Wilayah Hukum Polres Pohuwato sejak tahun 2014 sampai dengan April 2016 tidaklah sedikit. Berdasarkan hasil penelitian penulis perbuatan cabul yang dilakukan oleh anak mendominasi seluruh jumlah tindak pidana yang terjadi di Wilayah Polres Pohuwato.

Dari sekian banyak tindak pidana yang dilakukan oleh anak tersebut dipengaruhi oleh beberapa faktor. Menurut Bapak Markus Loris Pusut (Wawancara 26 April 2016) bahwa :

"beberapa faktor yang menyebabkan terjadinya tindak pidana yang dilakukan oleh anak yaitu Faktor keluarga, faktor pendidikan (putus sekolah), faktor pergaulan. Faktor keluarga biasanya pelaku berasal dari keluarga yang broken home, faktor pendidikan dalam hal ini adalah anak yang melakukan tindak pidana telah putus sekolah dan tidak berniat untuk sekolah lagi dan terakhir faktor pergaulan dimana anak pelaku tindak pidana dalam bergaul tidak memilah mana teman yang baik untuk masa depan dan mana teman yang dapat memberikan pengaruh buruk". 
Penyebab anak melakukan tindak pidana bukan saja pada terdapat pada faktor diatas, mengingat tindak pidana pencabulan dan pemerkosaan yang dominan terjadi di Wilayah Hukum Polres Pohuwato. Faktor kemajuan teknologi informasi yang memungkinkan anak dengan mudah mengakses situs-situs yang mengandung muatan pornografi menyebabkan anak yang belum matang secara psikologis bukan hanya menonton dan berkhayal tetapi juga melanjutkan aksinya menjadi suatu perbuatan cabul.

Pelaksanaan diversi kepada anak yang melakukan tindak pidana tidak selalu berjalan dengan mulus. Dari jumlah kasus yang terjadi sejak 2014-2016 tidak semua kasus berhasil dilakuakn diversi, ada juga beberapa kasus yang akhirnya harus dilimpahkan ke Jaksa Penuntut Umum. Berikut ini merupakan data tentang pelaksanaan diversi yang dilaksanakan oleh Unit PPA Polres Pohuwato

Berdasarkan data diatas pada tahun 2015 terdapat kasus sebanyak 21 kasus yang mana 9 kasus yang telah SP3, 12 kasus yang dilimpahkan ke Jaksa Penuntut Umum dan 3 Kasus yang berhasil di diversi. Pada tahun 2016 sampai dengan bulan april terdapat 10 kasus yang mana 4 kasus sedang di proses, 1 kasus SP3 , 4 kasus yang dilimpahkan ke Jaksa Penuntut Umum, dan 1 kasus berhasil di diversi.

Kendala Unit PPA Polres Pohuwato dalam melakukan diversi menurut Bapak Loris Pusut yaitu :

"Kendala yang dihadapi oleh penyidik dalam melakukan diversi yaitu di tingkat kabupaten pohuwato belum adanya instansi Bapas karena apabila penyidik polres melakukan upaya diversi masih manyurat ke Bapas Provinsi sehingga pelaksanaannya memakan waktu".

Belum adanya instansi Bapas di Kabupaten pohuwato sebagai pendukung keberhasilan diversi merupakan faktor yang sangat berpengaruh. Keberadaan Bapas sangat diperlukan dalam hal memberikan pertimbangan sesuai dengan amanat Pasal 9 UU SPPA. Selain itu batas waktu yang hanya 3 hari berdasarkan pasal 28 UU SPPA dapat menjadi kendala karena jarak antara Kabupaten Pohuwato dengan Kota Gorontalo yang memakan waktu tempuh 4 jam perjalanan. Adapun isi pasal 28 menyatakan : 
"Hasil Penelitian Kemasyarakatan wajib diserahkan oleh Bapas kepada Penyidik dalam waktu paling lama 3 x 24 (tiga kali dua puluh empat) jam setelah permintaan penyidik diterima".

Selain dari kendala tersebut diatas terdapat juga kendala lain yakni pihak korban tidak ingin kasusnya di selesaikan secara diversi karena kerugiaan secara imateriil yang diderita korban menyebabkan orang tua korban mengiginkan kasus tersebut di teruskan sampai pada pengadilan.

Berdasarkan kendala-kendala yang dihadapi tersebut Penyidik Polres Pohuwato yang menangani tindak pidana yang dilakukan oleh anak selalu berupaya agar kasus anak tersebut berhasil di diversi sehingga keadilan restorative dapat tercapai sehingga anak tidak perlu di hadapkan di depan Pengadilan

\section{PENUTUP}

Polres Pohuwato dalam melakukan penyidikan tindak pidana yang dilakukan oleh anak di tangani oleh Unit Perlindungan Perempuan dan Anak (UPPA). Dimulai dari tahap penyelidikan, penangkapan, penahanan sampai pada tahap penyidikan dilakukan sesuai dengan amanat dari UU Sistem Peradilan Pidana Anak. Penyidik dalam melakukan diversi, mendapatkan pertimbangan dari BAPAS. Selain itu penyidik juga berperansebagaifasilitator/mediator untuk melakukan musyawarah dengan melibatkan anak dan orang tua/walinya, korban dan orang tua/walinya, pembimbing kemasyarakatan, pekera sosial professional berdasarkan pendekatan restorative.

Kendala yang dihadapi oleh Penyidik Polres Pohuwato dalam melakukan diversi yaitu belum adanya BAPAS di wilayah Kabupaten Pohuwato sehingga menyulitkan penyidik untuk berkoordinasi dalam hal meminta pertimbangan dalam melakukan diversi. Selain itu pihak korban terkadang tidak ingin berdamai sehingga diversi yang diupayakan oleh Penyidik tidak tercapai. 


\section{DAFTAR PUSTAKA}

Angger Sigit Pramukti \& Fuadi Primaharsya, 2015. Sistem Peradilan Pidana Anak, Yogyakarta : Pustaka Yustisia.

Bagir Manan, 2008, Restoractive Justice (suatu perkenalan), Rangkaian Pemikiran dalam Dekade Terakhir, Analisis Komprehensif tentang Hukum oleh 68 Akadertrisi dan Praktisi Hukum, Perum Percetakan Negara Republik Indonesia, Jakarta.

Barda Nawawi Arief, 1998. Beberapa Aspek Kebijakan Penegakan Dan Pengembangan Hukum Pidana, Bandung: Citra Aditya Bakti.

Candra Gautama, 2000, Konvensi Hak Anak Panduan bagi Jurnalis, Jakarta: LSPP.

IGAA Apshari Pinatih dan Rai Setiabudi, Diversi Terhadap Anak Yang Berhadapan Dengan Hukum Dalam Pistem Pidana Anakhttp://ojs.unud.ac.id/index.php/kerthawicara/article/viewFile/8316/61 $\underline{99}$

Lamintang P.A.F. 1997, “Dasar-dasar Hukum Pidana di Indonesia”, PT. Citra Aditya Bakti : Bandung.

Leden Merpaung, 2005, “Asas, Teori, Praktik Hukum Pidana”, Sinar Grafika : Jakarta Lilik Mulyadi, Wajah Sistem Peradilan Pidana Anak di Indonesia, Bandung: PT. Alumni,

Lushiana Primasari,2010, “Keadilan Restoratif Dan Pemenuhan Hak Asasi Bagi Anak Yang Berhadapan Dengan Hukum", http://lushiana.staff.uns.ac.id/pdf.

Lili Rasjidi, , 2008, Pembangunan Sistem Hukum Dalam Rangka Pembinaan Hukum Nasional, Butir-Butir Pemikiran dalam Hukum, Memperingati 70 Tahun Prof , Dr, B, Arief Sidharta, SH, Bandung, Refika Aditama.

Marlina, 2010, Pengantar Konsep Diversi dan Restorative Justice dalam Hukum Pidana, Medan, USU Press. 
Maidin Gultom, 2008. Perlindungan Hukum Terhadap Anak dalam Sistem Peradilan Pidana Anak di Indonesia, PT. Refika Aditama, Bandung.

Maulana Hassan Wadong, 2000, Advokasi dan Hukum Perlindungan Anak, Jakarta: PT Grasindo.

MR. Roeslan Saleh, 1983 , Perbuatan Pidana Dan Pertanggung Jawaban Pidana, Jakarta, Pasar Baru. 